\title{
Developing a Historical Phenology Dataset through Community Involvement for Climate Change Research
}

\author{
Lori Petrauski'1, Sheldon 0wen², George Constantz ${ }^{3}$, James T. Anderson ${ }^{1}$ \\ ${ }^{1}$ Division of Forestry and Natural Resources, West Virginia University, Morgantown, WV, USA \\ ${ }^{2}$ West Virginia University Extension Service, Morgantown, WV, USA \\ ${ }^{3} 818$ Great Plains Dr., Capon Bridge, WV, USA \\ Email: wetland@wvu.edu
}

How to cite this paper: Petrauski, L., Owen, S., Constantz, G. and Anderson, J.T. (2020) Developing a Historical Phenology Dataset through Community Involvement for Climate Change Research. American Journal of Climate Change, 9, 11-22.

https://doi.org/10.4236/ajcc.2020.91002

Received: November 15, 2019

Accepted: February 18, 2020

Published: February 21, 2020

Copyright $\odot 2020$ by author(s) and Scientific Research Publishing Inc. This work is licensed under the Creative Commons Attribution International License (CC BY 4.0).

http://creativecommons.org/licenses/by/4.0/

\begin{abstract}
There has been an increased effort to utilize untapped sources of historical phenological data such as museum specimens, journals written by nature-minded citizens, and dated photographs through local phenology projects for climate change research. Local phenology projects have contributed greatly to our current understanding of phenological changes over time and have an important role in the public's engagement with natural history, but there are also significant challenges in finding and analyzing historical data. The West Virginia Climate History Project collected historical phenology data (1890-2015) from citizens in West Virginia with scientific and cultural results. We discuss the development of the project, issues we overcame, recommendations for future projects, and the conservation value of local phenology projects. Local phenology projects lend value to climate change research and conservation education. Policy directed towards supporting humanities grants and museum collections, including herbariums, is crucial in the success of these projects.
\end{abstract}

\section{Keywords}

Historical Phenology, Community Phenology, Citizen Science, Conservation Phenology

\section{Introduction}

Phenology, the timing of biological events in relation to seasons, has become popular due to its public accessibility [1], potential for scientific education [2], and use in tracking responses to climate change [3]. With the rise of phenology, there is a need to uncover historic phenology data so researchers can track changes 
over time. There has been a surge in attempts by researchers to utilize untapped sources of historical phenological data such as museum specimens, journals written by nature-minded citizens, and dated site-specific photographs [4] [5] [6].

Historical phenological observations have been used to create baselines for bird migration [7] [8] first flowering dates [9] [10] and leaf-out dates [11] [12]. Researchers have used phenological data found in journals of naturalist-minded authors as a baseline to compare with current dates of phenological events to estimate how climate change is affecting the timing of phenophases [12] [13]. These isolated studies, which involve local communities in research on familiar flora and fauna, are important for understanding individual organisms' responses to changes in climate.

Currently, the USA National Phenology Network (USA-NPN) attempts to synthesize data from individuals and small phenology projects, increase internetwork communication, and promote the practical use of phenological data [14] [15], as well as increase public awareness of phenology, climate change, and the scientific process [16] [17]. However, the implementation of these databases is relatively recent (USA-NPN was created in 2007) and establishing baseline data is still a challenge for phenological research [18] [19] [20]. Researchers have had to use creative methods to gather long-term baseline data, including the use of herbarium specimens, observations from diaries, and photographs [21].

There is a need for long-term phenological datasets in West Virginia to assess the current and future effects of climate change, as well as to set the stage for future citizen science projects. These are the goals of the West Virginia Climate History Project (WVCHP). Previous long-term studies have been done using historical observations from well-known people such as Henry David Thoreau [21] or Aldo Leopold [13], but this project demonstrates that reliable, long-term datasets can be found in any area with observant citizens. The purposes of this paper are to outline the WVCHP, advise other local phenological projects, and discuss the conservation value of local phenology projects.

\section{Uncovering and Processing Historical Sources}

The WVCHP began with public outreach in January 2015, in the hopes of finding individuals with archival sources of phenology data. Through presentations with local naturalist groups, informational fliers sent to public libraries, a press release through the university, an online project blog, and a West Virginia Public Radio interview, we attempted to reach interested citizens and find leads on potential data. With each outreach effort, we were offered suggestions, email addresses, and names of other people to contact for assistance with the project.

The most significant breakthrough in finding phenological data was the start of our relationship with the Brooks Bird Club, a naturalist group in West Virginia that was founded in 1932. The club's official publication, The Redstart, was the single most data-rich source used during this project. Our communications with their current members led us to other individuals with excellent historical records. Relationships we forged with local naturalist groups contributed to the success 
of this project more than any other factor; $78 \%$ ( $n=5614$ observations) of the data gathered through this project were directly related to these relationships.

Once the data sources were located, the task of transcribing the records began. Transcribing data from handwritten notes, journals, and lists ( $24 \%$ of the data, $n$ $=1350$ observations) required patience and investigative skills; whereas capturing data from newsletters, lists, or herbarium-labels was more efficient. The species, location, date, and phenophase were recorded for each phenological observation into an electronic format. One issue we encountered when working with these sources was the question of the difference between a phenological and a biological observation. For example, an entry in a personal journal could mention an American black bear (Ursus americanus) sighting in West Virginia, but the observation is not associated with seasonality. On the other hand, a journal entry that notes a bear with a young cub would have merit as a breeding phenology observation. We recorded phenophases and their definitions based on guidelines set by the USA-NPN [22].

At the start of our project, we had no preferences for specific species, phenophase, or season. After we discovered the first several sources, we saw the most potential in finding data regarding avian spring migration and spring wildflower blooming. Our interest in avian phenology was inspired by the Brooks Bird Club and the data potential of herbarium specimens triggered our interest in wildflower phenology. Advantages of using herbarium specimens for phenological studies include long-term temporal coverage, broad geographic area, and availability of valuable data plus reliable metadata [23]. Most of our search focused on where we could find first arrival dates of migrating birds through West Virginia and flowering dates of spring ephemeral wildflowers, which describes much of the data collected. We collected phenological data from personal journals, dated photographs, personal birding lists, herbarium specimens, Brooks Bird Club records, and center collections (Table 1 ) as long as they were accompanied by sufficient metadata.

Once we began analyzing specific phenophases and species, we had to overcome the issues associated with combining datasets from multiple observers. Observer skill, time taken each week for observation, and distance covered during observation could differ among observers and bias the data [21]. Phenology data are especially prone to this issue due to the sensitivity to timing of these observations. For both analyses, avian first arrival dates and wildflower blooming dates, the data sources were evaluated for credibility and accuracy before combining the datasets. Specifically for first arrival dates, more observers may result in seemingly earlier arrival dates [24] [25]. We reconciled our avian sources with these issues by arguing that all observers were experienced naturalists who visited a variety of habitats to observe migrating species and that the data from each source were gathered by groups of people more often than by single individuals, which improved consistency among sources. Similar avian datasets from multiple observers and sources have been analyzed with defensible results [5] [8]. 
Table 1. Data assembled in the West Virginia Climate History Project.

\begin{tabular}{|c|c|c|c|c|c|}
\hline Source Type & Collector & Location of record & Description & Timeframe & $\begin{array}{c}\text { No. } \\
\text { Observations }\end{array}$ \\
\hline Personal Record & $\begin{array}{l}\text { Lost Hollow } \\
\text { Families }\end{array}$ & Miller's personal records & $\begin{array}{l}\text { Personal journals with handwritten } \\
\text { entries on spring and fall phenology } \\
\text { in Hardy County, WV }\end{array}$ & $1973-1978$ & 134 \\
\hline $\begin{array}{c}\text { History } \\
\text { Center Record }\end{array}$ & Earl Brooks & $\begin{array}{l}\text { West Virginia Regional } \\
\text { History Center }\end{array}$ & $\begin{array}{l}\text { Handwritten ornithological } \\
\text { notes of breeding and migration }\end{array}$ & $1890-1915$ & 919 \\
\hline $\begin{array}{l}\text { Naturalist } \\
\text { Group Record }\end{array}$ & $\begin{array}{l}\text { Brooks } \\
\text { Bird Club }\end{array}$ & Brooks Bird Club records & $\begin{array}{l}\text { Printed spring bird arrival dates in the } \\
\text { club's newsletter, The Redstart }\end{array}$ & $1933-2014$ & 4558 \\
\hline Personal Record & Kay Evans & $\begin{array}{l}\text { Old Hemlock, Preston } \\
\text { County, West Virginia }\end{array}$ & $\begin{array}{l}\text { Personal journals with handwritten } \\
\text { entries on spring and fall phenology }\end{array}$ & 1939-1996 & 233 \\
\hline Personal Record & $\begin{array}{l}\text { George } \\
\text { Brieding }\end{array}$ & $\begin{array}{l}\text { Mike Brieding's } \\
\text { personal records }\end{array}$ & $\begin{array}{l}\text { Typed lists of avian arrival } \\
\text { dates throughout } \mathrm{WV}\end{array}$ & $1950-2009$ & 823 \\
\hline Personal Record & $\begin{array}{l}\text { Edwin } \\
\text { D. Michael }\end{array}$ & $\begin{array}{l}\text { Michael's } \\
\text { personal records }\end{array}$ & $\begin{array}{l}\text { Typed descriptions of phenology } \\
\text { in Canaan Valley, WV }\end{array}$ & $2009-2011$ & 52 \\
\hline Personal Record & John Weems & Weem's personal records & $\begin{array}{l}\text { Handwritten notes of plant phenology } \\
\text { in the Core Arboretum, Morgantown, WV }\end{array}$ & 1980 & 64 \\
\hline Herbarium & Various & $\begin{array}{l}\text { Fairmont State University } \\
\text { Herbarium, Fairmont, WV }\end{array}$ & Pressed flower specimens & $1963-1981$ & 11 \\
\hline Herbarium & Various & $\begin{array}{c}\text { Marshall University } \\
\text { Herbarium, Huntington, WV }\end{array}$ & Pressed flower specimens & $1928-2001$ & 186 \\
\hline Herbarium & Various & $\begin{array}{l}\text { University of Charleston } \\
\text { Herbarium, Charleston, WV }\end{array}$ & Pressed flower specimens & 1968 & 1 \\
\hline Herbarium & Various & $\begin{array}{l}\text { West Virginia University } \\
\text { Herbarium, Morgantown, WV }\end{array}$ & Pressed flower specimens & $1890-2013$ & 125 \\
\hline Herbarium & Various & $\begin{array}{c}\text { George B. Rossbach } \\
\text { Herbarium, Buckhannon, WV }\end{array}$ & Pressed flower specimens & 1929-1999 & 37 \\
\hline Herbarium & Various & $\begin{array}{l}\text { Carnegie Museum of Natural } \\
\text { History, Pittsburgh, PA }\end{array}$ & Pressed flower specimens & $1930-1988$ & 17 \\
\hline Herbarium & $\begin{array}{l}\text { Andrew } \\
\text { Walker }\end{array}$ & Old Fields, WV & Pressed flower specimens & 2013 & 2 \\
\hline Personal Record & $\begin{array}{l}\text { David } \\
\text { Smaldone }\end{array}$ & Morgantown, WV & $\begin{array}{l}\text { Dated photographs of flowers in the } \\
\text { Core Arboretum, Morgantown, WV }\end{array}$ & $2005-2015$ & 19 \\
\hline
\end{tabular}

WV refers to West Virginia, USA and PA refers to Pennsylvania, USA.

Possible issues with the wildflower blooming analyses were reduced by choosing species with a short blooming-window of one to two weeks, which negated problems associated with "first" phenophase analyses [26]. The main concern we faced with analyzing blooming dates was identifying locations of each blooming observation to calculate elevation and local climatic conditions. The location information offered on herbarium labels was used to pinpoint blooming locations with ArcGIS Version 10.3, but the level of detail varied for each location description. This variation in detail increased the likelihood that factors such as hillshade and aspect, which have been shown to explain variation in flowering phenology [27], could be confounding variables. Still, the high number of flowering 
observations analyzed was sufficient to overcome sampling bias within the data [28]. Overall, issues with combining historical datasets should be evaluated on a case-to-case basis that depends on the phenophase and species being analyzed.

\section{Conservation Value}

Local phenology projects have contributed greatly to understanding phenological changes over time [5] [8] [29] and have an important role in the public's engagement with natural history [6]. Local phenology projects are especially relevant in the context of climate change [30], due to their contribution to recovering long-term phenological data [31] and the connection between phenology and climate change [32]. Because recording phenological data is relatively straight-forward, phenology attracts a wide range of people with varying scientific experience, and therefore can impact how people understand climate change [1]. Local phenology projects can take advantage of this accessibility and offer a rare connection between familiar organisms and a global context.

The data collected by local phenology projects can be scientifically and culturally significant. Education and engagement of the public with climate change issues remain key components in the future success of conservation efforts [33]. Additionally, historical insights into species loss, changes in plant communities, the effects of land-use change, and urbanization are unique to each locality and can be used as a public reflection of human impacts on familiar places [34]. Specifically, the WVCHP encompassed a large, topographically variable area $(62,259$ $\mathrm{km}^{2}$, covering four ecoregions, average elevation $=420 \mathrm{~m}$, elevation range $=73$ $1482 \mathrm{~m}$ ) across a great temporal extent (1890-2015). Such scope is a common advantage of citizen science projects and makes this type of research important for landscape-level conservation [35]. This project enabled us to collect data on private lands, which pose challenges for traditional sampling methods [36].

Long-term phenological datasets can be used to explore how relationships between native and invasive species phenologies may influence management practices [37], such as the scheduling of prescribed burning [38] and herbicide application [39]. In these cases, understanding the phenologies of native and invasive plants have facilitated improved management practices to protect native species and prevent the spread of invasives. Local historical phenology datasets can be used to understand the makeup of past plant communities [21], predict future competitive advantages of native and invasive plants [12], and give valuable perspectives on the locale of invasive species [40] [41].

Many studies linking phenology to climate change focus on sweeping conclusions that do not specifically address local management actions [42], but we argue that local phenology projects can be used to impact management, especially if it is prioritized at the beginning of the project. For example, determining historical patterns of phenology to predict future changes in migration or breeding of game birds could help optimize hunting seasons [43]. Similarly, exploring the historical relationships among temperature, aquatic insect emergence, and fish 
spawning could contribute to revising fishing regulations and identifying potential threats to aquatic ecosystems [44]. Climate-driven phenological mismatches could affect local populations including those species that are already threatened [45], such as the Cerulean Warbler (Setophaga cerulea) in the Central Appalachians that relies on mature forests for breeding. The ability to predict the vulnerability to climate change of certain species is a crucial first step for adjusting local management actions.

For example, the West Virginia white butterfly (Pieris virginiensis), a rare butterfly found in the Central Appalachians, has been declining in part because of the spread of exotic garlic mustard (Alliaria petiolata) throughout their range. A. petiolata is in the same family (Brassicaceae) as $P$. virginiensis's host plants, and $P$. virginiensis lays its eggs on $A$. petiolata where the larva cannot survive therefore negatively impacting butterfly reproduction. Understanding the phenology patterns of both $A$. petiolata and $P$. virginiensis would allow for better local management of both the threatened butterfly and the invasive plant. For example, $A$. petiolata control should be implemented in early spring before the emergence of $P$. virginiensis.

Butterflies have shifted their phenologies three times more than spring plants in recent years [46]. Butterfly species shift their emergence phenology relative to temperature [47], but their response to changes in climate is highly dependent on their larval host species [48]. Understanding not only flowering patterns, but also butterfly phenology in relation to climate change is important for pollinator conservation [49]. For example, $P$. virginiensis depends on early flowering species for food and oviposition. The early-flowering Cardamine diphylla, is a common host plant of $P$. virginiensis. The early senescence of $C$. diphylla has resulted in decreased larval survival or reproductive success of $P$. virginiensis. A local phenology project investigating this host plant and butterfly mismatch could increase the success of managing a threatened species.

\section{Evaluation and Recommendations for Future Projects}

Overall, the WVCHP collected 7181 historical phenology observations covering 404 different species, including 258 bird species, 37 species of trees and shrubs, 100 species of herbs and forbs, 2 insect species, 1 mammal, 3 amphibian species, and 3 grasses. Most of the observations (80.2\%) were used to analyze avian spring migration and wildflower blooming. The remaining $19.8 \%$ covers a range of species and phenophases that we were unable to analyze due to too few consistent observations.

The success of this project in finding useful avian and wildflower phenology data was due to our concentrated focus on these two categories. This highlights the potential for more phenological data to be uncovered in this region, if a focus is set on particular species and phenophases. We expect that there are more useable data in this region that we have not had the opportunity to compile. Phenological information about spring insect emergence would contribute to our 
understanding of ecosystem phenology and the potential risks of mismatch, because insects are a link between avian and plant phenologies [6], both of which have been studied more thoroughly than insect phenology.

One of the greatest potential sources of phenological data is herbarium specimens, which have been highlighted in recent literature [11] [50] [51] and confirmed with this study. Herbariums are rich sources of phenological information that can be used to evaluate species presence and geographic distributions [23]. There is a disconnected relationship between the usefulness of herbarium specimens for research and the amount of funding given to enhancing these collections. There has been a decrease in funding for herbariums over the last few decades [52] despite an increase in using herbarium specimens as data sources [53]. Digitizing herbarium specimens has increased the usefulness and availability of these data and has contributed to the increased use of herbarium specimens in research. Unfortunately, small collections are seldom cataloged due to tight budgets, which makes them difficult to access [54]. Another issue facing herbariums is a decrease in addition of new plant specimens [55] [56], which could be contributing to the antiquated reputation of herbariums and their subsequent decrease in funding. The herbariums used in this study were strewn throughout West Virginia in various universities with no central herbarium database or consistent organization. Using herbarium specimens from these under-utilized and hard-to-access collections increased the distinctiveness and temporal range of our dataset. This demonstrates the value of small herbariums and the importance of continued funding for maintaining and growing herbariums and museum collections.

Humanities grants have also experienced decreases in funding, but we argue that these grants play an important role in local phenology projects and ensuing climate change research. Historical personal journals were a key source of phenology data in this study, and humanities grants allow for libraries to preserve these irreplaceable data points. The handwritten journals we uncovered carried both cultural and scientific significance that enriched the breadth of our project. This highlights the importance of funding for humanities grants.

We did not encounter a shortage of historical data, but finding current data in handwritten journals and herbariums was more difficult. To create a complete temporal dataset, we used alternative data sources to augment our current phenological observations. For our avian analysis, we supplemented current data with observations from eBird, an online community of birders [57]. For the wildflower analysis, we used dated photographs from a West Virginian citizen to increase the number of current blooming observations. The increased use of electronic phenological monitoring programs, such as Project BudBurst [58] and Nature's Notebook, are instrumental sources of current data that should be integrated with historical phenological data.

Local phenology projects are categorized as citizen science [59], but unless there is substantial effort to include educational outcomes and create educational materials, there is little evidence that the project will have educational impacts 
[2] [30] [36]. The main outcomes of this project were scientific with potential to develop educational outcomes in the future. We recommend establishing strong educational outcomes for future projects that could include recruiting volunteers to process historical data sources, developing educational materials, and creating a volunteer monitoring component to supplement current observations of specific species of interest to the community. As previously stated, our relationship with the Brooks Bird Club and other naturalist groups contributed significantly to the success of this project, which highlights the importance of public outreach and communication.

The West Virginia Climate History Project has demonstrated the usefulness of a local phenology project for uncovering previously unused phenological data, engaging local communities with climate change research, and finding scientifically relevant insights about the effects of climate change on ecosystems. Local phenology projects have a pertinent role in the future of climate change research and conservation education. Policy supporting humanities grants and museum collections, including herbariums, is crucial in the success of these projects.

\section{Acknowledgements}

The authors thank many people who contributed observations and access to data. Funding and logistical support was provided by the U.S. Department of Agriculture Northeast Climate Hub (Grant 14-JV-11242306-094), the West Virginia Humanities Council (Grant 14086), and the West Virginia University Natural History Museum. J. T. Anderson was supported by the National Science Foundation under Cooperative Agreement No. OIA-1458952, the USDA National Institute of Food and Agriculture, McIntire Stennis project WVA00117, and the West Virginia Agricultural and Forestry Experiment Station during manuscript preparation.

\section{Conflicts of Interest}

The authors declare no conflicts of interest regarding the publication of this paper.

\section{References}

[1] Lawrence, A. (2009) The First Cuckoo in Winter: Phenology, Recording, Credibility and Meaning in Britain. Global Environmental Change, 19, 173-179. https://doi.org/10.1016/j.gloenvcha.2009.01.006

[2] Bonney, R., Cooper, C.B., Dickinson, J., Kelling, S., Phillips, T., Rosenberg, K.V. and Shirk, J. (2009) Citizen Science: A Developing Tool for Expanding Science Knowledge and Scientific Literacy. BioScience, 59, 977-984. https://doi.org/10.1525/bio.2009.59.11.9

[3] Visser, M.E. and Both, C. (2005) Shifts in Phenology Due to Global Climate Change: The Need for a Yardstick. Proceedings of the Royal Society B: Biological Sciences, 272, 2561-2569. https://doi.org/10.1098/rspb.2005.3356

[4] Miller-Rushing, A.J., Primack, R.B., Primack, D. and Mukunda, S. (2006) Photo- 
graphs and Herbarium Specimens as Tools to Document Phenological Changes in Response to Global Warming. American Journal of Botany, 93, 1667-1674. https://doi.org/10.3732/ajb.93.11.1667

[5] Ellwood, E.R., Primack, R.B. and Talmadge, M.L. (2010) Effects of Climate Change on Spring Arrival Times of Birds in Thoreau's Concord from 1851 to 2007. The Condor, 112, 754-762. https://doi.org/10.1525/cond.2010.100006

[6] Primack, R.B. and Miller-Rushing, A.J. (2012) Uncovering, Collecting, and Analyzing Records to Investigate the Ecological Impacts of Climate Change: A Template from Thoreau's Concord. BioScience, 62, 170-181.

https://doi.org/10.1525/bio.2012.62.2.10

[7] Zelt, J., Courter, J., Arab, A., Johnson, R. and Droege, S. (2012) Reviving a Legacy Citizen Science Project to Illuminate Shifts in Bird Phenology. International Journal of Zoology, 2012, Article ID: 710710. https://doi.org/10.1155/2012/710710

[8] Travers, S.E., Marquardt, B., Zerr, N.J., Finch, J.B., Boche, M.J., Wilk, R. and Burdick, S.C. (2015) Climate Change and Shifting Arrival Date of Migratory Birds over a Century in the Northern Great Plains. The Wilson Journal of Ornithology, 127, 43-51. https://doi.org/10.1676/14-033.1

[9] Miller-Rushing, A.J., Inouye, D. and Primack, R.B. (2008) How Well Do First Flowering Dates Measure Plant Responses to Climate Change? The Effects of Population Size and Sampling Frequency. Journal of Ecology, 96, 1289-1296. https://doi.org/10.1111/j.1365-2745.2008.01436.x

[10] Abu-Asab, M.S., Peterson, P.M., Shetler, S.G. and Orli, S.S. (2001) Earlier Plant Flowering in Spring as a Response to Global Warming in the Washington DC, Area. Biodiversity and Conservation, 10, 597-612.

[11] Everill, P.H., Primack, R.B., Ellwood, E.R. and Melaas, E.K. (2014) Determining Past Leaf-out Times of New England's Deciduous Forests from Herbarium Specimens. American Journal of Botany, 101, 1293-1300. https://doi.org/10.3732/ajb.1400045

[12] Polgar, C.A. and Primack, R.B. (2013) Leaf out Phenology in Temperate Forests. Biodiversity Science, 21, 111-116. https://doi.org/10.3724/SP.J.1003.2013.06187

[13] Bradley, N.L., Leopold, A.C., Ross, J. and Huffaker, W. (1999) Phenological Changes Reflect Climate Change in Wisconsin. Proceedings of the National Academy of Sciences of the United States of America, 96, 9701-9704. https://doi.org/10.1073/pnas.96.17.9701

[14] van Vliet, A.J.H., et al. (2003) The European Phenology Network. International Journal of Biometeorology, 47, 202-212.

[15] Rosemartin, A.H., Crimmins, T.M., Enquist, C.A.F., Gerst, K.L., Kellermann, J.L., Posthumus, E.E., Denny, E.G., Guertin, P., Marsh, L. and Weltzin, J.F. (2014) Organizing Phenological Data Resources to Inform Natural Resource Conservation. Biological Conservation, 173, 90-97. https://doi.org/10.1016/j.biocon.2013.07.003

[16] Haggerty, B. and Mazer, S. (2008) The Phenology Handbook: A Guide to Phenological Monitoring for Students, Teachers, Families, and Nature Enthusiasts. UCSB Phenology Stewardship Program. University of California, Santa Barbara, CA.

[17] Meymaris, K., Henderson, S., Alaback, P. and Havens, K. (2008) Project Budburst: Citizen Science for All Seasons. AGU Fall Meeting Abstracts, 2008, ED21B-0614.

[18] Betancourt, J.L., Schwartz, M.D., Breshears, D.D., Brewer, C.A., Frazer, G., Gross, J.E., Mazer, S.J., Reed, B.C. and Wilson, B.E. (2007) Evolving Plans for the USA National Phenology Network. Eos, Transactions American Geophysical Union, 88, 211-211. https://doi.org/10.1029/2007EO190007 
[19] Miller-Rushing, A.J., Høye, T.T., Inouye, D.W. and Post, E. (2010) The Effects of Phenological Mismatches on Demography. Philosophical Transactions of the Royal Society of London B: Biological Sciences, 365, 3177-3186. https://doi.org/10.1098/rstb.2010.0148

[20] Weltzin, J.F. (2011) The USA National Phenology Network; Taking the Pulse of Our Planet (No. 2011-3023). US Geological Survey, 3023.

[21] Miller-Rushing, A.J. and Primack, R.B. (2008) Global Warming and Flowering Times in Thoreau's Concord: A Community Perspective. Ecology, 89, 332-341. https://doi.org/10.1890/07-0068.1

[22] Denny, E.G., Gerst, K.L., Miller-Rushing, A.J., Tierney, G.L., Crimmins, T.M., Enquist, C.A.F., Guertin, P., Rosemartin, A.H., Schwartz, M.D., Thomas, K.A. and Weltzin, J.F. (2014) Standardized Phenology Monitoring Methods to Track Plant and Animal Activity for Science and Resource Management Applications. International Journal of Biometeorology, 58, 591-601.

[23] Vellend, M., Brown, C.D., Kharouba, H.M., McCune, J.L. and Myers-Smith, I.H. (2013) Historical Ecology: Using Unconventional Data Sources to Test for Effects of Global Environmental Change. American Journal of Botany, 100, 1294-1305. https://doi.org/10.3732/ajb.1200503

[24] Courter, J.R., Johnson, R.J., Stuyck, C.M., Lang, B.A. and Kaiser, E.W. (2013) Weekend Bias in Citizen Science Data Reporting: Implications for Phenology Studies. International Journal of Biometeorology, 57, 715-720.

[25] Arab, A., Courter, J.R. and Zelt, J. (2016) A Spatio-Temporal Comparison of Avian Migration Phenology Using Citizen Science Data. Spatial Statistics, 18, 234-245. https://doi.org/10.1016/j.spasta.2016.06.006

[26] Petrauski, L., Owen, S.F., Constantz, G.D. and Anderson, J.T. (2019) Changes in Flowering Phenology of Cardamine concatenata and Erythronium americanum over 111 Years in the Central Appalachians. Plant Ecology, 220, 817-828.

[27] Jackson, M. (1966) Effects of Microclimate on Spring Flowering Phenology. Ecology, 47, 407-415. https://doi.org/10.2307/1932980

[28] Primack, D., Imbres, C., Primack, R., Miller-Rushing, A. and Del Tredici, P. (2004) Herbarium Specimens Demonstrate Earlier Flowering Times in Response to Warming in Boston. American Journal of Botany, 91, 1260-1264. https://doi.org/10.3732/ajb.91.8.1260

[29] McDermott, M.E. and DeGroote, L.W. (2016) Long-Term Climate Impacts on Breeding Bird Phenology in Pennsylvania, USA. Global Change Biology, 22, 3304-3319. https://doi.org/10.1111/gcb.13363

[30] Dickinson, J.L., Shirk, J., Bonter, D., Bonney, R., Crain, R.L., Martin, J., Phillips, T. and Purcell, K. (2012) The Current State of Citizen Science as a Tool for Ecological Research and Public Engagement. Frontiers in Ecology and the Environment, 10, 291-297. https://doi.org/10.1890/110236

[31] Morellato, L.P.C., Alberton, B., Alvarado, S.T., Borges, B., Buisson, E., Camargo, M.G.G., Cancian, L.F., Carstensen, D.W., Escobar, D.F.E., Leite, P.T.P., Mendoza, I., Rocha, N.M.W.B., Soares, N.C., Silva, T.S.F., Staggemeier, V.G., Streher, A.S., Vargas, B.C. and Peres, C.A.(2016) Linking Plant Phenology to Conservation Biology. Biological Conservation, 195, 60-72. https://doi.org/10.1016/j.biocon.2015.12.033

[32] Root, T.L., Price, J.T., Hall, K.R., Schneider, S.H., Rosenzweig, C. and Pounds, J.A. (2003) Fingerprints of Global Warming on Wild Animals and Plants. Nature, 421, 57-60. https://doi.org/10.1038/nature01333

[33] Burch, S., Berry, P. and Sanders, M. (2014) Embedding Climate Change Adaptation 
in Biodiversity Conservation: A Case Study of England. Environmental Science \& Policy, 37, 79-90. https://doi.org/10.1016/j.envsci.2013.08.014

[34] Haywood, B.K. (2014) A "Sense of Place" in Public Participation in Scientific Research. Science Education, 98, 64-83. https://doi.org/10.1002/sce.21087

[35] Devictor, V., Whittaker, R.J. and Beltrame, C. (2010) Beyond Scarcity: Citizen Science Programmes as Useful Tools for Conservation Biogeography. Diversity and Distributions, 16, 354-362. https://doi.org/10.1111/j.1472-4642.2009.00615.x

[36] Dickinson, J.L., Zuckerberg, B. and Bonter, D.N. (2010) Citizen Science as an Ecological Research Tool: Challenges and Benefits. Annual Review of Ecology, Evolution, and Systematics, 41, 149-172. https://doi.org/10.1146/annurev-ecolsys-102209-144636

[37] Wolkovich, E.M. and Cleland, E.E. (2011) The Phenology of Plant Invasions: A Community Ecology Perspective. Frontiers in Ecology and the Environment, 9, 287-294. https://doi.org/10.1890/100033

[38] Benefield, C.B., DiTomaso, J.M., Kyser, G.B. and Tschohl, A. (2001) Reproductive Biology of Yellow Starthistle: Maximizing Late-Season Control. Weed Science, 49, 83-90. https://doi.org/10.1614/0043-1745(2001)049[0083:RBOYSM]2.0.CO;2

[39] Xu, C.Y., Griffin, K.L. and Schuster, W.S.F. (2007) Leaf Phenology and Seasonal Variation of Photosynthesis of Invasive Berberis thunbergii (Japanese Barberry) and Two Co-Occurring Native Understory Shrubs in a Northeastern United States Deciduous Forest. Oecologia, 154, 11-21. https://doi.org/10.1007/s00442-007-0807-y

[40] Crall, A.W., Jarnevich, C.S., Young, N.E., Panke, B.J., Renz, M. and Stohlgren, T.J. (2015) Citizen Science Contributes to Our Knowledge of Invasive Plant Species Distributions. Biological Invasions, 17, 2415-2427. https://doi.org/10.1007/s10530-015-0885-4

[41] Hoffberg, S.L. and Mauricio, R. (2016) The Persistence of Invasive Populations of Kudzu Near the Northern Periphery of Its Range in New York City Determined from Historical Data 1, 2. The Journal of the Torrey Botanical Society, 143, 437-442. https://doi.org/10.3159/TORREY-D-16-00032.1

[42] Enquist, C., Kellermann, J., Gerst, K. and Miller-Rushing, A. (2014) Phenology Research for Natural Resource Management in the United States. International Journal of Biometeorology, 58, 579-589. https://doi.org/10.1007/s00484-013-0772-6

[43] Guzmán, J.L. and Arroyo, B. (2015) Predicting Winter Abundance of Woodcock Scolopax rusticola Using Weather Data: Implications for Hunting Management. European Journal of Wildlife Research, 61, 467-474.

https://doi.org/10.1007/s10344-015-0918-4

[44] Donnelly, A., Caffarra, A. and O'Neill, B.F. (2011) A Review of Climate-Driven Mismatches between Interdependent Phenophases in Terrestrial and Aquatic Ecosystems. International Journal of Biometeorology, 55, 805-817.

https://doi.org/10.1007/s00484-011-0426-5

[45] Robinson, R.A., Crick, H.Q.P., Learmouth, J.A., Maclean, I.M.D., Thomas, C.D., Bairlein, F., Forchhammer, M.C., Francis, C.M., Gill, J.A., Godley, B.J., Hardwood, J., Hays, G.C., Huntley, B. Hutson, A.M., Pierce, G.J., Rehfisch, M.M., Sims, D.W., Santos, M.B., Sparks, T.H., Stroud, D.A. and Visser, M.E. (2009) Travelling through a Warming World: Climate Change and Migratory Species. Endangered Species Research, 7, 87-99. https://doi.org/10.3354/esr00095

[46] Parmesan, C. (2007) Influences of Species, Latitudes and Methodologies on Estimates of Phenological Response to Global Warming. Global Change Biology, 13, 1860-1872. https://doi.org/10.1111/j.1365-2486.2007.01404.x 
[47] Kharouba, H., Paquette, S., Kerr, J. and Vellend, M. (2014) Predicting the Sensitivity of Butterfly Phenology to Temperature over the Past Century. Global Change Biology, 20, 504-514. https://doi.org/10.1111/gcb.12429

[48] Posledovich, D., Toftegaard, T., Wiklund, C., Ehrlén, J. and Gotthard, K. (2015) The Developmental Race between Maturing Host Plants and Their Butterfly Herbivore-the Influence of Phenological Matching and Temperature. Journal of Animal Ecology, 84, 1690-1699. https://doi.org/10.1111/1365-2656.12417

[49] Davis, S. and Cipollini, D. (2014) How Environmental Conditions and Changing Landscapes Influence the Survival and Reproduction of a Rare Butterfly, Pieris virginiensis (Pieridae). Journal of the Lepidopterists' Society, 68, 61-65. https://doi.org/10.18473/lepi.v68i1.a9

[50] Gaira, K., Uppeandra, D. and Belwal, O. (2011) Potential of Herbarium Records to Sequence Phenological Pattern: A Case Study of Aconitum heterophyllum in the Himalayas. Biodiversity and Conservation, 20, 2201-2210. https://doi.org/10.1007/s10531-011-0082-4

[51] Calinger, K.M., Queenborough, S. and Curtis, P.S. (2013) Herbarium Specimens Reveal the Footprint of Climate Change on Flowering Trends across North-Central North America. Ecology Letters, 16, 1037-1044. https://doi.org/10.1111/ele.12135

[52] Ahrends, A., Rahbek, C., Bulling, M.T., Burgess, N.D., Platts, P.J., Lovett, J.C., Kindemba, V.W., Owen, N., Sallu, A.N., Marshall, A.R., Mhoro, B.E., Fanning, E. and Marchant, R.(2011) Conservation and the Botanist Effect. Biological Conservation, 144, 131-140. https://doi.org/10.1016/j.biocon.2010.08.008

[53] Lavoie, C. (2013) Biological Collections in an Ever Changing World: Herbaria as Tools for Biogeographical and Environmental Studies. Perspectives in Plant Ecology, Evolution and Systematics, 15, 68-76. https://doi.org/10.1016/j.ppees.2012.10.002

[54] Deng, B. (2015) Plant Collections Get Pruned Back: North America's Herbaria Wilt under Budget Pressure. Nature, 523, 16. https://doi.org/10.1038/523016a

[55] Prather, L.A., Alvarez-Fuentes, O., Mayfield, M.H. and Ferguson, C.J. (2004) The Decline of Plant Collecting in the United States: A Threat to the Infrastructure of Biodiversity Studies. Systematic Botany, 29, 15-28.

[56] Beauvais, M.P., Pellerin, S., Dubé, J. and Lavoie, C. (2017) Herbarium Specimens as Tools to Assess the Impact of Large Herbivores on Plant Species. Botany, 95, 153-162. https://doi.org/10.1139/cjb-2016-0206

[57] Sullivan, B.L., Wood, C.L., Iliff, M.J., Bonney, R.E., Fink, D. and Kelling, S. (2009) eBird: A Citizen-Based Bird Observation Network in the Biological Sciences. Biological Conservation, 142, 2282-2292. https://doi.org/10.1016/j.biocon.2009.05.006

[58] Project BudBurst (2017) Project BudBurst: An Online Database of Plant Phenological Observations. Project BudBurst, Boulder, CO. http://www.budburst.org

[59] Wiggins, A. and Crowston, K. (2011) From Conservation to Crowdsourcing: A Typology of Citizen Science. 2011 44th Hawaii International Conference on System Sciences, Kauai, HI, 4-7 January 2011, 1-10.

https://doi.org/10.1109/HICSS.2011.207 